\title{
CARDIOPROTECTIVE EFFECT OF FISETIN ON LYSOSOMAL ENZYME ACTIVITIES OF NORMAL AND ISOPROTERENOL-INDUCED MYOCARDIAL INFARCTION IN MALE WISTAR RATS
}

\author{
MYTHILY PANNEERSELVAM ${ }^{1}$, DEVIKA P. T ${ }^{2 *}$ \\ Department of Biochemistry, Mohamed Sathak College of Arts and Science, Chennai, Tamil Nadu, India. Email: p.vaishali27@gmail.com
} Received: 18 December 2018, Revised and Accepted: 20 January 2019

\begin{abstract}
Objective: This study aims to evaluate the cardioprotective effect of fisetin on change in the activities of lysosomal enzymes in isoproterenol (ISO)induced myocardial infarction (MI) in male albino Wistar rats.

Methods: Rats were orally pretreated with fisetin (30 mg/kg body weight) daily for 30 days. After the pretreatment period, ISO (100 mg/kg body weight) was subcutaneously administered to rats at intervals of $24 \mathrm{~h}$ for 2 consecutive days.

Results: The activities of $\beta$-glucuronidase, $\beta$ - $N$-acetylglucosaminidase, $\beta$-galactosidase, cathepsin-B, and cathepsin-D were significantly $(* \mathrm{p}<0.05)$ increased in serum and the heart of ISO-induced rats. Pre-treatment with fisetin daily for 30 days to ISO-induced rats significantly prevented these activities and restored their activities to near normal. Oral treatment with fisetin ( $30 \mathrm{mg} / \mathrm{kg}$ body weight) to normal control rats did not show any significant effect.
\end{abstract}

Conclusion: We have concluded that fisetin protects the $\beta$-glucuronidase, $\beta$ - $N$-acetylglucosaminidase, $\beta$-galactosidase, cathepsin-B, and cathepsin-D against ISO-induced MI. The observed effects might be due to the free radical-scavenging and membrane-stabilizing effect of fisetin.

Keywords: Myocardial infarction, Isoproterenol, Fisetin and Lysosomal enzymes.

(C) 2019 The Authors. Published by Innovare Academic Sciences Pvt Ltd. This is an open access article under the CC BY license (http://creativecommons. org/licenses/by/4. 0/) DOI: http://dx.doi.org/10.22159/ajpcr.2019.v12i3.30974

\section{INTRODUCTION}

Cardiovascular disease remains one of the most deaths causing disease for both men and women [1]. Myocardial infarction (MI) makes an increase in contribution to mortality and morbidity statistics in developing countries due to their lifestyle changes mostly in urban areas [2]. MI occurs as a outcome of prolonged imbalance between coronary supply of blood and myocardial oxygen demand. It is well known that free radicals generated in ischemic tissues cause severe stresses, which result in degradation of tissue defense system, leading to cardiac damage [3]. Isoproterenol (ISO), a synthetic catecholamine and $\beta$-adrenergic agonist, causes severe stress in the myocardium, resulting in infarct-like necrosis of the heart tissue [4]. The model of ISO-induced cardiotoxicity is considered as most well-known experimental method [5]. ISO-induced myocardial necrosis involves changes in membrane permeability that brings myocardial membrane integrity and loss of function [6].

Recently, attention has been focused on phytochemicals and flavonoids, derived from different plant species as effective therapeutic agents in the management of cardiovascular disease due to their antioxidant nature [7]. Fisetin (Fig. 1) is a dietary phenolic flavonoid rich in strawberry, onion, persimmon, and cucumber. It has a wide variety of pharmacological activities such as antioxidant and anti-inflammatory activity mainly acting as a free radical scavenger. Fisetin is able to scavenge free radicals produced by ISO, as a result of its electron donating capacity, due to the presence of two hydroxyl groups on one ring and a hydroxyl group in another ring [8].

Lysosomes are membrane-bound structures that contain hydrolytic enzymes capable of degrading most of the cellular constituents. In addition, lysosomes play a major role in secretion and transport processes [9]. Lysosomal enzymes are the most important mediators of acute MI. Lysosomal hydrolases play a key role in the inflammatory process. ISO-induced MI results in increased lysosomal enzyme activity that may be responsible for heart tissue damage [10].
In the first phase of the experiment, we have observed the protective effect of fisetin on lipid peroxides, enzymic, and non-enzymic antioxidants in ISO-induced myocardial-infarcted rats [11]. However, any in vivo study on the protective effect of fisetin on lysosomal hydrolases has not been previously carried out. Therefore, the present investigation was undertaken to study the alterations in the activities of lysosomal enzymes and subcellular fractions during ISO-induced MI and the effect of fisetin pre-treatment in reducing the extent of damage in the myocardium.

\section{METHODS}

Experimental animals

The experiments were carried out according to the guidelines of the committee and approved by the Institutional Animal Ethical Committee (IAEC/XLI/03/CLBMCP/2017). All the experiments were done with a healthy male albino Wistar rats, weighing 150-180 g. They were housed in polypropylene cages $(47 \mathrm{~cm} \times 34 \mathrm{~cm} \times 20 \mathrm{~cm})$ lined with husk, renewed every $24 \mathrm{~h}$ under a $12: 12 \mathrm{~h}$ light dark cycle at around $22^{\circ} \mathrm{C}$. The rats had free access to tap water and food.

\section{Drug and chemicals}

Fisetin and ISO hydrochloride were purchased from Sigma (St. Louis, MO, USA).

\section{Induction of experimental MI}

ISO $(100 \mathrm{mg} / \mathrm{kg})$ was dissolved in normal saline and subcutaneously injected to rats at an interval of $24 \mathrm{~h}$ for 2 days.

\section{Experimental protocol}

The animals were grouped into six rats in each group:

- Group I: Normal control rats received standard pelleted diet and orally administered with $0.5 \%$ dimethyl sulfoxide (DMSO) for 30 days.

- Group II: Rats orally administered with fisetin $(30 \mathrm{mg} / \mathrm{kg}$ body weight/day, dissolved in $0.5 \%$ DMSO) for 30 days. 
- Group III: Rats subcutaneously administered with ISO (100 mg/kg body weight/day) dissolved in physiological saline, for 2 days for the induction of MI.

- Group IV: Rats pretreated with fisetin (30 mg/kg body weight/day), for 30 days, before the induction of MI as described for Group III.

At the end of the experimental design period (i.e., $24 \mathrm{~h}$ after last injection of ISO), the control and experimental groups were sacrificed. Blood samples were collected and serum was separated by centrifugation.

\section{Processing of heart sample}

Heart tissues were removed and washed in physiological saline containing $0.8 \%$ sodium chloride. A tissue sample was homogenized in $4.0 \mathrm{ml} 0.1 \mathrm{M}$ Tris-Hcl buffer (pH 7.4). The homogenate was centrifuged and the supernatant used for biochemical estimations.

\section{Separation of subcellular fraction}

The tissues were removed and the homogenate was used to ultracentrifugation, and the fractions were separated as follows: Structural proteins, nucleus, and cell debris at $6000 \mathrm{rpm}$ for $10 \mathrm{~min}$; mitochondria at $5000 \mathrm{rpm}$ for $10 \mathrm{~min}$; lysosomes at $15,000 \times \mathrm{g}$ for $10 \mathrm{~min}$; microsomes at 120,000 rpm for $30 \mathrm{~min}$; and supernatant, the cytosol. Subtractions were treated with Triton X-100 (final concentration of $0.3 \% \mathrm{v} / \mathrm{v}$ ) for $20 \mathrm{~min}$ to the determination of enzymes activities [12]

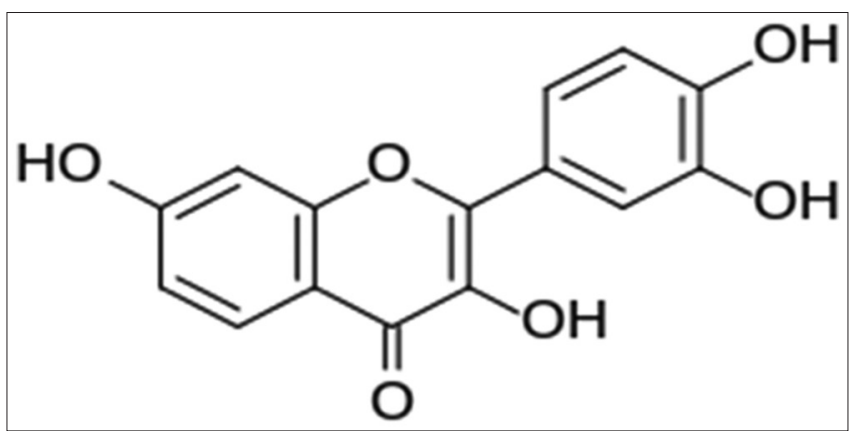

Fig. 1: Structure of the fisetin

\section{Assay of lysosomal enzymes}

The activities of $\beta$-glucuronidase, $\beta$ - $N$-acetylglucosaminidase, and $\beta$-galactosidase were estimated by the methods of Kawai and Anno [13], Moore and Morris [14], and Conchie et al. [15], respectively. Activities of cathepsin-D and B were determined by the methods of Sapolsky et al. [16] and Barrett, [17] respectively. The content of protein was estimated by the method of Lowry et al. [18].

\section{Statistical analysis}

Statistical analysis was performed by one-way analysis of variance followed by Duncan's multiple range test (DMRT) using Statistical Package for the Social Sciences software version 17.00. Data were expressed as mean \pm standard deviation for six rats in each group. ${ }^{*} \mathrm{p}<0.05$ was considered to be statistically significant.

\section{RESULTS}

Table 1 shows the activities of $\beta$-glucuronidase, $\beta$ - $N$-acetylglucosaminidase, $\beta$-galactosidase, and cathepsin-B and $\mathrm{D}$ in serum of control and experimental groups of rats. The activities of these enzymes were increased significantly $\left({ }^{*} \mathrm{p}<0.05\right)$ in serum of ISO-induced rats when compared to normal control rats. Oral pre-treatment with fisetin $(30 \mathrm{mg} / \mathrm{kg})$ for $30 \mathrm{~d}$ significantly $\left({ }^{*} p<0.05\right)$ decreased the activities of enzymes in ISO-induced rats when compared to ISO alone treated rats groups.

Table 2 shows the activities of $\beta$-glucuronidase, $\beta$ - $N$-acetylglucosaminidase, $\beta$-galactosidase, and cathepsin-B and $\mathrm{D}$ in the control heart and experimental groups of rats. The activities of these enzymes were significantly $\left({ }^{*} \mathrm{p}<0.05\right)$ increased in the heart of ISO-induced rats when compared to normal control rats. Pre-treatment with fisetin $(30 \mathrm{mg} / \mathrm{kg})$ significantly $\left({ }^{*} \mathrm{p}<0.05\right)$ decreased the activities of these enzymes in the heart of ISO-induced rats when compared to ISO alone induced rats.

Fig. 2 depicts the activity of $\beta$-glucuronidase in subcellular fractions of the heart in control and experimental groups of rats. The activity of $\beta$-glucuronidase was significantly $\left({ }^{*} \mathrm{p}<0.05\right)$ decreased in nuclear, mitochondrial, lysosomal, and microsomal fractions of the heart in ISO-induced rats when compared to normal control rats. $\beta$-glucuronidase activity in cytosolic fraction was significantly $\left({ }^{*} p<0.05\right)$ increased in ISO-treated rats when compared to normal control rats. Pre-treatment

Table 1: Effect of fisetin on activities of $\beta$-glucuronidase, $\beta$ - $N$-acetylglucosaminidase, $\beta$-galactosidase, and cathepsin-B and $D$ in serum of control and experimental group of rats

\begin{tabular}{|c|c|c|c|c|}
\hline Groups & $\begin{array}{l}\text { Normal } \\
\text { rats }\end{array}$ & $\begin{array}{l}\text { Normal+fisetin } \\
(30 \mathrm{mg} / \mathrm{kg})\end{array}$ & $\begin{array}{l}\text { ISO } \\
(100 \mathrm{mg} / \mathrm{kg})\end{array}$ & $\begin{array}{l}\text { Fisetin } \\
(30 \mathrm{mg} / \mathrm{kg})+\mathrm{ISO}\end{array}$ \\
\hline$\beta$-Glucuronidase (mmol of $\mathrm{p}$-nitrophenol liberated/h/mg protein) & $14.5 \pm 0.8^{\mathrm{a}}$ & $14.7 \pm 0.9^{a}$ & $25.4 \pm 1.8^{\mathrm{b}}$ & $16.6 \pm 0.8^{c}$ \\
\hline$\beta$-N-Acetylglucosaminidase (mmol of p-nitrophenol liberated/h/mg protein) & $24.5 \pm 1.8^{\mathrm{a}}$ & $25.2 \pm 1.9^{a}$ & $38.4 \pm 2.8^{\mathrm{b}}$ & $29.6 \pm 2.0^{c}$ \\
\hline$\beta$-Galactosidase (mmol of $\mathrm{p}$-nitrophenol liberated/h/mg protein) & $19.5 \pm 0.8^{\mathrm{a}}$ & $19.7 \pm 0.9^{\mathrm{a}}$ & $29.4 \pm 1.8^{\mathrm{b}}$ & $22.4 \pm 1.2^{\mathrm{c}}$ \\
\hline Cathepsin-B (mmol of p-nitrophenol liberated/h/mg protein) & $10.5 \pm 0.8^{\mathrm{a}}$ & $10.7 \pm 0.8^{\mathrm{a}}$ & $23.4 \pm 1.6^{\mathrm{b}}$ & $17.6 \pm 0.7^{\mathrm{c}}$ \\
\hline Cathepsin-D (mmol of tyrosine liberated/h/100 mg protein) & $19.5 \pm 1.7^{\mathrm{a}}$ & $19.9 \pm 1.8^{\mathrm{a}}$ & $35.4 \pm 2.7^{b}$ & $26.6 \pm 2.1^{c}$ \\
\hline
\end{tabular}

Each value is mean \pm SD for six rats in each group; values not sharing a common superscript $\left(\mathrm{a}, \mathrm{b}, \mathrm{c}\right.$,) differ significantly with each other $\left({ }^{*} \mathrm{p}<0.05\right.$, DMRT)

DMRT: Duncan's Multiple Range Test, ISO: Isoproterenol, SD: Standard deviation

Table 2: Effect of fisetin on the activities of $\beta$-glucuronidase, $\beta$ - $N$-acetylglucosaminidase, $\beta$-galactosidase, and cathepsin-B and $D$ in the heart of control and experimental groups of rats

\begin{tabular}{|c|c|c|c|c|}
\hline Groups & $\begin{array}{l}\text { Normal } \\
\text { rats }\end{array}$ & $\begin{array}{l}\text { Normal+fisetin } \\
(30 \mathrm{mg} / \mathrm{kg})\end{array}$ & $\begin{array}{l}\text { ISO } \\
(100 \mathrm{mg} / \mathrm{kg})\end{array}$ & $\begin{array}{l}\text { Fisetin } \\
(30 \mathrm{mg} / \mathrm{kg})+\text { ISO }\end{array}$ \\
\hline$\beta$-Glucuronidase (mmol of p-nitrophenol liberated/h/mg protein) & $24.5 \pm 1.7^{\mathrm{a}}$ & $24.8 \pm 1.8^{\mathrm{a}}$ & $43.4 \pm 2.8^{b}$ & $34.6 \pm 2.1^{c}$ \\
\hline$\beta$-N-Acetylglucosaminidase (mmol of p-nitrophenol liberated $/ \mathrm{h} / \mathrm{mg}$ protein) & $29.3 \pm 1.8^{\mathrm{a}}$ & $29.4 \pm 1.9^{a}$ & $53.4 \pm 3.8^{\mathrm{b}}$ & $39.3 \pm 2.6^{c}$ \\
\hline$\beta$-Galactosidase (mmol of $\mathrm{p}$-nitrophenol liberated/h/mg protein) & $39.5 \pm 2.2^{\mathrm{a}}$ & $39.8 \pm 2.3^{\mathrm{a}}$ & $52.3 \pm 2.9^{b}$ & $45.4 \pm 2.6^{c}$ \\
\hline Cathepsin-B (mmol of p-nitrophenol liberated/h/mg protein) & $20.5 \pm 2.1^{\mathrm{a}}$ & $20.9 \pm 2.0^{\mathrm{a}}$ & $43.4 \pm 2.6^{b}$ & $29.6 \pm 1.9^{c}$ \\
\hline Cathepsin-D (mmol of tyrosine liberated/h/100 mg protein) & $19.9 \pm 1.8^{\mathrm{a}}$ & $19.8 \pm 1.9^{\mathrm{a}}$ & $28.2 \pm 2.7^{b}$ & $23.1 \pm 2.1^{c}$ \\
\hline
\end{tabular}

Each value is mean \pm SD for six rats in each group; values not sharing a common superscript $(a, b, c)$ differ significantly with each other $(* p<0.05$, DMRT)

DMRT: Duncan's Multiple Range Test, ISO: Isoproterenol, SD: Standard deviation 


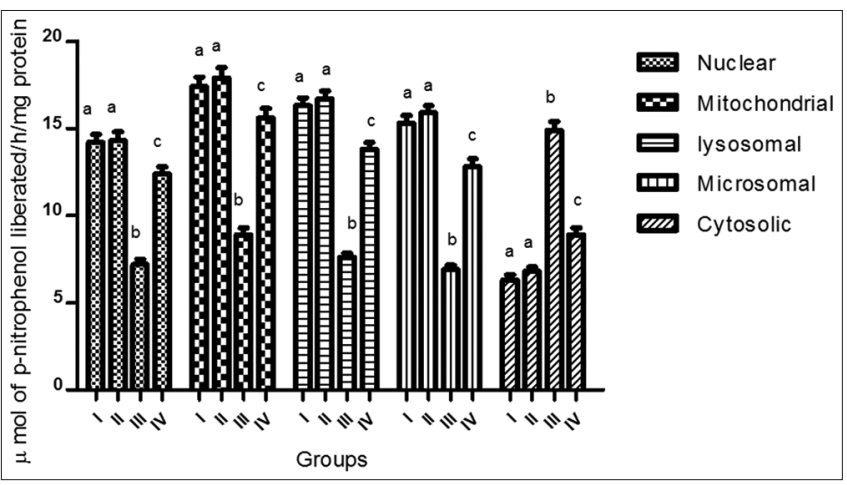

Fig. 2: Effect of fisetin on the activity of $\beta$-glucuronidase in subcellular fractions of the heart in normal and experimental groups of rats. Each value is mean \pm standard deviation for six rats in each group; values not sharing a common superscript

$\left(a, b\right.$, and c) differ significantly with each other $\left({ }^{*} p<0.05\right.$, Duncan's Multiple Range Test)

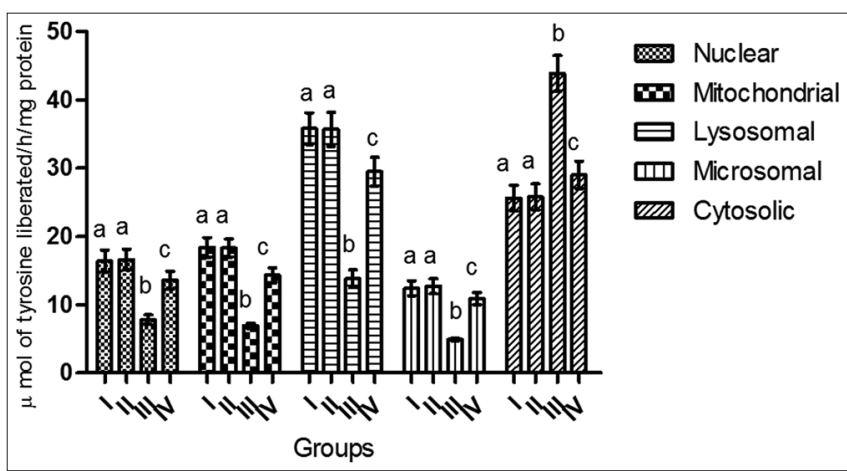

Fig. 3: Effect of fisetin on the activity of cathepsin-D in subcellular fractions of the heart in normal and experimental groups of rats. Each value is mean \pm standard deviation for six rats in each group; values not sharing a common superscript $(a, b$, and $c$,) differ significantly with each other $(p<0.05$, Duncan's Multiple Range Test)

with fisetin $(30 \mathrm{mg} / \mathrm{kg})$ to ISO-induced rats significantly $\left({ }^{*} \mathrm{p}<0.05\right)$ increased the activity of $\beta$-glucuronidase in nuclear, mitochondrial, lysosomal, and microsomal fractions of the heart and significantly $\left({ }^{*} \mathrm{p}<0.05\right)$ decreased in the cytosolic fraction of the heart. ISO-induced groups showed an increased ratio of cytosol to bound lysosomal activities and cytosol to total activity for $\beta$-glucuronidase in the heart. Pre-treatment with fisetin $(30 \mathrm{mg} / \mathrm{kg})$ to ISO-induced rats showed a decreased ratio of cytosol to lysosomal and cytosol to total activities.

Fig. 3 depicts the activity of cathepsin-D in subcellular fractions in the heart of normal and ISO-induced rats. The activity of cathepsin-D was significantly $\left({ }^{*} \mathrm{p}<0.05\right)$ lowered in nuclear, mitochondrial, lysosomal, and microsomal fractions in the heart of ISO-induced rats when compared to normal control rats. Cathepsin-D activity in cytosolic fraction of the tissues was significantly $(p<0.05)$ increased in ISOtreated rats when compared to normal control rats. Pre-treatment with fisetin $(30 \mathrm{mg} / \mathrm{kg})$ to ISO-induced rats significantly $\left({ }^{*} \mathrm{p}<0.05\right)$ increased the activity of cathepsin-D in nuclear, mitochondrial, lysosomal, and microsomal fractions and significantly $(\mathrm{p}<0.05)$ decreased in the cytosolic fraction of the heart. ISO-induced rats also showed an increased ratio of cytosol to bound lysosomal activities and cytosol to total activity for cathepsin-D in the heart.

\section{DISCUSSION}

The present study indicated that fisetin significantly cardioprotected against ISO-induced oxidative stress (reactive oxygen species [ROS]) and MI in rats. The cardiac hypertrophy after administration of ISO is possibly due to the intramuscular water accumulation and the formation of interstitial fibrosis, as well as invasion by inflammatory cells [19]. The lysosomal compartment is one of the important sites of intracellular protein degradation. It contains several hydrolytic enzymes that can degrade closely all cellular components. Administration of ISO induced to rats leads to a significantly increase of lysosomal enzyme activities in the serum and myocardium. Intracellular release of lysosomal enzymes following myocardial ischemia resulted in cell death [20]. It has been proposed that oxygen free radicals generated during ischemia in addition to the direct myocardial damaging effect may also be responsible for the myocardial damage through the release of lysosomal enzymes [21]. Lysosomes are membrane-bound structures that play an important role in secretion. Lysosomal hydrolytic enzymes are involved in the degradation of cellular constituents. The intracellular release of lysosomal enzymes and their extralysosomal activity may play a major role in the progressive changes that lead from reversible myocardial injury to irreversible MI [22]. Elevated activities of $\beta$-glucuronidase, $\beta$-N-acetylglucosaminidase, $\beta$-galactosidase, and cathepsin-B and D were observed in the serum and heart of ISOtreated rats. Fisetin could be maintaining the normal levels of their activities of heart tissues. Increased lipid peroxidation observed in ISOtreated rats could have resulted in leakage of serum and myocardial acid hydrolases from the enclosed sacs due to lysosomal membrane damage [23]. It has been shown that the cytosolic acid hydrolases released from the sarcoplasmic reticulum and from lysosomes induce the dysfunction and destruction of mitochondria, sarcolemma, and other organelles [24]. Pre-treatment with fisetin normalized the activities of lysosomal enzymes both in the serum and myocardium by its inhibitory effect on lipid peroxidation, thereby preventing lysosomal damage induced by ISO-treated rats [25]. Cathepsins are lysosomal proteases possibly involved in autophagic digestion of cytoplasm and myofibrillary and mitochondrial proteins [26]. The activities of $\beta$-glucuronidase and cathepsin-D in different fractions except cytosolic fraction were decreased in ISO-induced rats. The decreased activity of these enzymes in different fractions clearly shows decreased stability of the membranes [27]. Fisetin pre-treatment inhibits the release of these enzymes from the lysosomal and microsomal fractions. Fisetin is due to the stabilizing effect on the lysosomal and microsomal membranes in ISO-induced rats. Our study also showed that fisetin inhibits the release of enzymes as well as decrease the activity of the total lysosomal hydrolases, thereby enhancing the lysosomal stability. Fisetin has effective scavenger of free radicals under in vivo conditions. Antioxidant activities are mainly due to its hydroxyl groups at C-3, C-3', C- $4^{\prime}$, and C-7 positions and are enriched by carbonyl group at C-4. The presence of double bond between $\mathrm{C}-2$ and C-3 conjugated with the 4-oxo group also eases higher electron delocalization. The potent free radical scavenging activity of fisetin was attributed to the presence of the $\mathrm{C}$ ring group. Fisetin acts as antioxidant properties by scavenging ROS and also improved the endogenous system in ISO-treated rats and suggested that the fisetin might be peroxides scavenging and/or due to blocking the peroxidation of membrane lipids. In this study, highlighting the fisetin preserves the lysosomal, mitochondrial, and cytosol membrane integrity in the serum, heart, and fractions of ISOinduced rats.

\section{CONCLUSION}

The results of the present study indicated that the lysosomal hydrolases play an important role in ISO-induced MI and fisetin proved to be more protective in reducing the extent of lysosomal integrity in induced MI of rats.

\section{AUTHORS' CONTRIBUTIONS}

All the authors have contributed equally.

\section{CONFLICTS OF INTEREST}

The authors have declared no conflicts of interest. 


\section{REFERENCES}

1. Aronow WS. Epidemiology, pathophysiology, prognosis, and treatment of systolic and diastolic heart failure. Cardiol Rev 2006;14:108-24.

2. Boudina S, Laclau MN, Tariosse L, Daret D, Gouverneur G, BonoronAdèle $\mathrm{S}$, et al. Alteration of mitochondrial function in a model of chronic ischemia in vivo in rat heart. Am J Physiol Heart Circ Physiol 2002;282:H821-31.

3. Muruganandan S, Gupta S, Kataria M, Lal J, Gupta PK. Mangiferin protects the streptozotocin-induced oxidative damage to cardiac and renal tissues in rats. Toxicology 2002;176:165-73.

4. Jiang DJ, Tan GS, Ye F, Du YH, Xu KP, Li YJ, et al. Protective effects of xanthones against myocardial ischemia-reperfusion injury in rats. Acta Pharmacol Sin 2003;24:175-80.

5. Wexler BC. Myocardial infarction in young vs old male rats: Pathophysiologic changes. Am Heart J 1978;96:70-80.

6. Nirmala C, Puvanakrishnan R. Effect of curcumin on certain lysosomal hydrolases in isoproterenol-induced myocardial infarction in rats. Biochem Pharmacol 1996;51:47-51.

7. Dhawan S, Kapoor NK, Nityanand S. Effect of isoprenaline on lipid profile and cardiac enzymes in rats. Indian J Exp Biol 1978;16:376-8.

8. Banerjee SK, Maulik SK. Effect of garlic on cardiovascular disorders: A review. Nutr J 2002;1:4.

9. Decker RS, Poole AR, Griffin EE, Dingle JT, Wildenthal K. Altered distribution of lysosomal cathepsin D in ischemic myocardium. J Clin Invest 1977;59:911-21.

10. Ravichandran LV, Puvanakrishnan R, Joseph KT. Influence of isoproterenol-induced myocardial infarction on certain glycohydrolases and cathepsins in rats. Biochem Med Metab Biol 1991;45:6-15.

11. Mythily P, Devika PT. Cardioprotective effect of fisetin on lipid peroxide metabolism in isoproterenol induced myocardial infarction in male Wistar rats. Int J Innov Res Sci Eng Technol 2017;6:22306-14.

12. Sathish V, Ebenezar KK, Devaki T. Synergistic effect of nicorandil and amlodipine on lysosomal hydrolases during experimental myocardial infarction in rats. Biomed Pharmacother 2003;57:309-13.

13. Kawai Y, Anno K. Mucopolysaccharide-degrading enzymes from the liver of the squid, ommastrephes sloani pacificus. I. Hyaluronidase. Biochim Biophys Acta 1971;242:428-36.
14. Moore JC, Morris JE. A simple automated colorimetric method for determination of N-acetyl-beta-D-glucosaminidase. Ann Clin Biochem 1982;19:157-9.

15. Conchie J, Gelman AL, Levvy GA. Inhibition of glycosidases by aldonolactones of corresponding configuration. The C-4- and C-6-specificity of beta-glucosidase and beta-galactosidase. Biochem J 1967;103:609-15.

16. Sapolsky AI, Altman RD, Howell DS. Cathepsin D activity in normal and osteoarthritic human cartilage. Fed Proc 1973;32:1489-93.

17. Barrett AJ. A new assay for cathepsin B1 and other thiol proteinases. Anal Biochem 1972;47:280-93.

18. Lowry OH, Rosebrough NJ, Farr AL, Randall RJ. Protein measurement with the folin phenol reagent. J Biol Chem 1951;193:265-75.

19. Salah AR. Cardioprotective efficacy of taurine on lipid-metabolism of isoproterenol-induced myocardial infarction. Int J Pharm Pharm Sci 2016;8:135-41

20. Sudharsan PT, Mythili Y, Selvakumar E, Varalakshmi P. Lupeol and its ester ameliorate the cyclophosphamide provoked cardiac lysosomal damage studied in rat. Mol Cell Biochem 2006;282:23-9.

21. Garcia-Dorado D, Ruiz-Meana M. Propagation of cell death during myocardial reperfusion. News Physiol Sci 2000;15:326-30.

22. Kalra J, Prasad K. Oxygen free radicals and cardiac depression. Clin Biochem 1994;27:163-8.

23. Subashini R. Cardioprotective efficacy of Nelumbo nucifera Leaf extract on glycoprotein, membrane bound atpase and lysosomal enzymes against isoproterenol induced cardiotoxicity in Wistar rats. Int J Pharm Pharm Sci 2014;6:537-41.

24. Pillay CS, Elliott E, Dennison C. Endolysosomal proteolysis and its regulation. Biochem J 2002;363:417-29.

25. Devika PT, Prince PS. Preventive effect of (-)epigallocatechin-gallate (EGCG) on lysosomal enzymes in heart and subcellular fractions in isoproterenol-induced myocardial infarcted Wistar rats. Chem Biol Interact 2008;172:245-52.

26. Sano M, Takahashi Y, Yoshino K, Shimoi K, Nakamura Y, Tomita I, et al. Effect of tea (Camellia sinensis L.) on lipid peroxidation in rat liver and kidney: A comparison of green and black tea feeding. Biol Pharm Bull 1995;18:1006-8.

27. Ravens KG, Gudbjarnason S. Changes in the activities of lysosomal enzymes in infarcted canine heart muscle. Circ Res 1969;24:851-6. 